\title{
Employee share ownership in a unionised duopoly
}

\author{
Juan Carlos Bárcena-Ruiz ${ }^{1}$
}

\begin{abstract}
Profit sharing schemes have been analysed assuming Cournot competition and decentralised wage negotiations, and it has been found that firms share profits in equilibrium. This paper analyses a different remuneration system: employee share ownership. We find that whether firms choose to share ownership or not depends on both the type of competition in the product market and the way in which workers organise to negotiate wages. If wage setting is decentralised, under duopolistic Cournot competition both firms share ownership. If wage setting is centralised, only one firm shares ownership if the degree to which goods are substitutes takes an intermediate value; otherwise, the two firms share ownership. In this case, if the union sets the same wage for all workers neither firm shares ownership. Therefore, centralised wage setting discourages share ownership. Fi- nally, under Bertrand competition neither firm shares ownership regardless of how workers are organised to negotiate wages.
\end{abstract}

Keywords Compensation systems · Share ownership · Unions · Cournot · Bertrand

JEL Classification L13 J3 J51

Juan Carlos Bárcena-Ruiz

juancarlos.barcena@ehu.es

1 Departamento de Fundamentos del Análisis Económico I, Universidad del País Vasco, UPV/EHU, Avenida Lehendakari Aguirre, 83, 48015 Bilbao, Spain 